\title{
Nanoparticles Derived from Active Metabolites of Chaetomium cupreum CC3003 against Phytophthora Rot of Durian
}

\author{
Rujira Tongon and Kasem Soytong* \\ Department of Plant Production Technology, Faculty of Agricultural Technology, King Mongkut's Institute of Technology \\ Ladkrabang, Bangkok 10520, Thailand \\ *For correspondence: ajkasem@gmail.com; rutt1409@gmail.com \\ Received 03 February 2021; Accepted 04 December 2021; Published 30 January 2022
}

\begin{abstract}
Phytophthora rot of durian (Durio zibetinus L.) is a serious disease wherever the crop has been planted and the disease control customarily uses chemical fungicides reported to be resistant by pathogen. Alternative non-chemical control strategies are being investigated to produce safe food. The main objective of this research was to test the activity of metabolites from Chaetomium cupreum CC3003 in the form of crude materials and nanoparticles to control and induce immunity to Phytophthora palmivora causing rot of durian var. Monthong. The results showed that $P$. palmivora proved to be pathogenic to durian var. Monthong. C. cupreum CC3003 acted as an antagonist and $P$. palmivora was confirmed as the pathogen by morphological and molecular genetic identification. Effective doses $\left(\mathrm{ED}_{50}\right)$ of $\mathrm{CC}-\mathrm{E}, \mathrm{CC}-\mathrm{H}$ and $\mathrm{CC}-\mathrm{M}$ crude metabolites for spore inhibition were 60,97 and $140 \mathrm{mg} \cdot \mathrm{kg}^{-1}$, respectively. The research findings found that the diameters of nano CC-E, nano CC-H and nano CC-M were 534, 499 and $537 \mathrm{~nm}$, respectively. The nano CC-E, nano CC-H and nano CC-M demonstrated antifungal activity against $P$. palmivora with $\mathrm{ED}_{50}$ of 11,13 and $16 \mathrm{mg} \cdot \mathrm{kg}^{-1}$, respectively. The nanoparticles at low concentrations were more effective than crude metabolites at high concentrations. Nano-CC-E used to treat seedlings of durian resulted in the production of scopoletin which served as an immunity agent or elicitor against rot disease of durian. It is concluded that active metabolites derived from $C$. cupreum significantly inhibited $P$. palmivora and induced immunity through phytoalexin production. (C) 2022 Friends Science Publishers
\end{abstract}

Keywords: Chaetomium; Nanoparticles; Phytoalexin; Root rot; Durian

\section{Introduction}

Durian (Durio zibethinus L.) is native fruit of Southeast Asian countries, and is one of the most famous fruit in the world. In Thailand, the durian fruit is considered as the "King of Fruits". Each durian tree produces around 15-800 fruits in every fruiting season (Subhadrabandhu and Shodal 1997; Husin et al. 2018). Monthong variety genuinely means "golden pillow" in Thai. It's one of the popular varieties in Thailand and is characterized by triangular spikes, pale yellow fruit and a sweet test. Phytophthora palmivora (Butl.) is a destructive pathogen which infects various economic plants of over 2000 species including root rot in durian which is a serious problem leading to inferior quality and lower yield (Soytong 2010). In 1996, Erwin and Ribeiro reported that Phytophthora species are usually resistant to the fungicide metalaxyl leading to disease control failure. Biological control of plant pathogens has been developed in recent years to reduce environmental harm, costly application of fungicides and decrease disease incidence caused by Phytophthora spp. (Palmieri et al. 2019).
Chaetomium spp. is potential bio-control agents against different soil-borne pathogens. Many species of Chaetomium have demonstrated suppression of the growth of plant pathogens through competition, antibiosis and a combination of mechanisms (Shanthiyaa et al. 2013). Biological control by Chaetomium spp. was reported against Melampsora puplicola, Rhizoctonia solani, Pythium ultimum, Fusarium sporotrichioides and Colletotrichum gloeosporioides (Thiep and Soytong 2015; Jiang et al. 2017). Chaetomium cupreum CC3003 used in this research is reported to release azaphilones including rotiorinols $\mathrm{A}-\mathrm{C}$, stereoisomers named (-)-rotiorin and a known compound, rubrorotiorin. Rotiorinols $\mathrm{A}$ and $\mathrm{C}$, (-)-rotiorin and rubrorotiorin were reported to inhibit Candida albicans with $\mathrm{IC}_{50}$ values of $10.5,16.7,24.3$ and $0.6 \mathrm{mg} . \mathrm{kg}^{-1}$, respectively (Kanokmedhakul et al. 2006). Moreover, Tann and Soytong (2016) found that C. cupreum CC3003 inhibited Cuvularia lunata in bi-culture tests, and its metabolites including crude hexane, crude EtOAc and crude methanol extracts inhibited spore production of the tested pathogen with the $\mathrm{ED}_{50}$ of $6.4,0.8$ and $7.8 \mathrm{mg} \cdot \mathrm{kg}^{-1}$, respectively. 
Agricultural nanotechnology is being investigated for plant disease control to reduce the application of chemical fungicides which are harzadous to human beings, unbalance the agroecosystem and cause toxic residues in agricultural products. It has become a new tool to re-structure the materials at the atomic level including the formulation of organic materials as fine particles (Li et al. 2011; Soutter 2012). The scienists have recently examined the biological properties of organic nanomaterials (Elibol et al. 2003), applied in crop production (Soutter 2012; Ditta 2012). The bioactive substances from natural products can be constructed as nanoparticles that can easily penetrate through plant cells, and this increases the stability of effective compounds and decreases leaching from plant surface after application (Perlatti et al. 2013). This technique can increase the efficacy plant disease management (Rai and Ingle 2012) by allowing formulation of disease control products in liquid or powder forms to apply to plants (Ditta 2012). Moreover, Tongon et al. (2018) reported that nanoparticles derived from $C$. brasiliense inhibited $P$. palmivora with an $\mathrm{ED}_{50}$ of $1.08 \mathrm{mg} \cdot \mathrm{kg}^{-1}$ and decreased the root rot disease of durian as well as increased plant growth parameters.

Phytoalexins are understood to be involved in plant defense (Ahuja et al. 2012) and they can accumulate in healthy plant cells surrounding wounded or infected tissue (Deverall 1982). Abiotic elicitors are capable of inducing phytoalexins in many crops (Angelova et al. 2006; Yean et al. 2009) while biotic elicitors are also reported to elicite phytoalexins (Liu et al. 1995). Glazebrook and Ausubel (1994) stated that plants can produce phytoalexins after facing abiotic and biotic stress, and this process elicits the production of toxins which attack pathogens. Phytoalexins can help to delay pathogen maturation, interfer with metabolism and prevent pathogen reproduction. It is important in plant defense to inhibit pathogen colonization. Gnonlonfin et al. (2012) stated that many plants produce coumarins with antimicrobial activities. A coumarin compound, scopoletin (6-methoxy-7-hydroxycoumarin), isolated from plant species was found to produce antifungal compound in tobacco plants against Phytophthora spp. The objectives of the current research were to investigate the ability of crude metabolites, and nanoparticles constructed from $C$. cupreum $\mathrm{CC} 3003$ to inhibit $P$. palmivora DD01 and induce immunity to durian rot.

\section{Materials and Methods}

\section{Isolation of pathogen and pathogenicity test}

Phytophthora spp. DD01 was isolated by using a baiting technique following the method described by Soytong (1989). Infested soil samples were placed in sterilized Petri dishes, sterile water was added, $1 \times 1 \mathrm{~cm}$ pieces of durian leaves were added, and the dishes were incubated at room temperature. After 2 days of incubation, sporangia typical of
Phytophthora spp. were observed under light microscopy and isolates were transferred to water agar (WA) in Petri dishes. The WA plates were maintained at room temperature $\left(27-30^{\circ} \mathrm{C}\right)$, single colonies were sub-cultured to potato dextrose agar (PDA) and re-isolated until pure cultures were obtained, which were maintained in PDA for further experiments.

Pathogenicity tests were done using detached leaves and root inoculation of durian seedling var. Monthong. Healthy durian detached leaves were sterilized with $10 \%$ sodium hypochlorite then wounded by a sterilized needle. Agar plugs of the pathogen were inoculated on the wound site of detached leaves. The controls were processed similarly using an agar plug without the pathogen. Root inoculation was done using 4-month-old durian seedlings planted in planting bags (size 6 inch). Sporangial suspensions $\left(1 \times 10^{5}\right.$ sporangia/mL) of the $P$. palmivora isolate were prepared and applied to the soil and basal stem of the test plants at the rate of $20 \mathrm{~mL} /$ plant. The experiment was repeated four times. Disease incidence (\%) was measured as the number of infected plants/ total number of tested plants $\mathrm{x} 100$. Disease rating index was recorded as $0=$ healthy plants, and 3 = seriously infected plants (Soytong 2010).

\section{Chaetomium antagonistic fungus}

C. cupreum strain CC 3003 used in this study was previously reported to release rotiorinols $\mathrm{A}-\mathrm{C},(-)$-rotiorin and rubrorotiorin which were found to inhibit Candida albicans (Kanokmedhakul et al. 2006). The culture was morphologically identified according to Arx et al. (1986) and Soytong and Quimio (1989).

\section{Morphological and molecular phylogenic identification}

Phytophthora spp. DD01 was cultured on PDA and periodically observed morphologically. Agar containing the fungal sporangia and other structures of DD01 were cut into $1 \times 1 \mathrm{~cm}$ piece and placed in sterilized Petri dishes containing sterile distilled water. Plates were incubated at $28-30^{\circ} \mathrm{C}$ for 5 days before observation under a light microscope and photos were taken photos using MoticPlus 2.0 software. Genomic DNA of Chaetomium isolates were extracted using the CTAB method (Graham et al. 1994). Identification the pathogen at the molecular level used universal primers ITS 1 (5'TCC GTA GGT GAA CCT GCG G 3') and ITS 4 (5'TCC TCC GCT TAT TGA TAT GC 3) to amplify the internal transcribed spacer (ITS) rDNA region of isolate DD01, under previously described PCR conditions (Ferrer et al. 2001).

\section{Bi-culture test}

Phytophthora spp. DD01 was cultured in PDA for 7 days and $0.3 \mathrm{~cm}$ diameter discs were cut from the periphery of colonies and placed opposite a disc of the antagonist at the opposite edge of $9 \mathrm{~cm}$ diameter PDA plates. Bi-culture 
plates were incubated and periodically observed for 30 days. Colony growth and sporangia of Phytophthora spp. DD01 were observed and data were recorded from bi-culture and control plates. Sporangia were counted by haemacytometer. Data were calculated included the colony growth and sporangial inhibition as follows:

$$
\text { Inhibition }(\%)=100 \times(\mathrm{A}-\mathrm{B}) / \mathrm{A}
$$

Where $\mathrm{A}=$ sporangial number or colony size of Phytophthora spp. DD01 in control plates; B = sporangial number or colony size of Phytophthora spp. DD01 in biculture plates. Data were subjected to analysis of variance (ANOVA) and Duncan's multiple range test (DMRT) at $\mathrm{P}=$ 0.05 and 0.01 were computed to compare treatment means.

\section{Testing crude metabolites from $C$. cupreum $\mathrm{CC} 3003$}

C. cupreum CC3003 was cultured in potato dextrose broth (PDB) medium for 30 days at room temperature $\left(27-30^{\circ} \mathrm{C}\right)$, then the fungal biomass was dried at room temperature and crude metabolites were obtained following the methods of Kanokmedhakul et al. (2006). The dried fungal biomass of C. cupreum CC3003 was ground into fine powder using an electric grinder. It was extracted by hexane $(1: 1 \mathrm{v} / \mathrm{v})$ for 72 $\mathrm{h}$, then passed through Whatman No. 4 filter paper to separate the marc and hexane filtrate. Crude hexane extract was obtained using a rotary vacuum evaporator. The marc was soaked in ethyl acetate $(1: 1 \mathrm{v} / \mathrm{v})$ for $72 \mathrm{~h})$ and filtered then evaporated to get crude ethyl acetate extract. Marc from ethyl acetate was further extracted in methanol $(1: 1 \mathrm{v} / \mathrm{v})$ to yield crude methanol extract.

Each crude extract was tested for inhibitory activity against $P$. palmivora DD01 in two factor factorial experiments using a Completely Randomized Design (CRD); the experiment was repeated four times. Agar plugs of $P$. palmivora were placed on $\mathrm{PDA}$ plates $(5 \mathrm{~cm}$ in diameter) in which each crude extract was incorporated at concentrations of $0,10,50,100,500$ and 1,000 mg. $\mathrm{kg}^{-1}$. Each crude extract was dissolved in $2 \%$ dimethyl sulfoxide (DMSO). All tested crude extract concentrations were autoclaved at $121^{\circ} \mathrm{C}(15 \mathrm{psi})$ for $30 \mathrm{~min}$. The agar plugs (0.3) $\mathrm{cm}$ of $C$. cupreum CC3003 were transferred to the middle of plates containing each tested sample concentration and incubated for 7 days. Data were statistically computed by analysis of variance of the colony growth and sporangia number and inhibition percentage using the above formulae. Colony growth and sporangia inhibition were used to compute the effective dose $\mathrm{ED}_{50}$ by probit analysis through SPSS Statistics v. 23.0 software (IBM Co., Armonk, NY, USA).

\section{Evaluation of nanoparticles derived from $C$. cupreum against $P$. palmivola}

Nanoparticles were derived from crude extracts from $C$. cupreum CC3003 by using an electrospinning machine following the method of Dar and Soytong (2014) to get 3 samples of nanoparticles as follows: nano $\mathrm{CC}-\mathrm{H}$ (from crude hexane), nano $\mathrm{CC}-\mathrm{E}$ (from crude ethyl acetate) and nano CC-M (crude methanol). Each nanoparticle was observed under Scanning Electron Microscope (SEM). The nanoparticles of nano $\mathrm{CC}-\mathrm{H}$, nano $\mathrm{CC}-\mathrm{E}$ and nano $\mathrm{CC}-\mathrm{M}$ were tested for antimicrobial activity against $P$. palmivora DD01 (root rot of durian). The research used two factor factorial experiments arranged in a CRD and was performed four times. Treatment combinations were expressed as factor A (nanoparticles of CC-H, CC-E and CC-M), and factor $\mathrm{B}$ (concentrations of $0,3,5,10$ and $15 \mathrm{ppm}$ ). One drop of $2 \%$ dimethyl sulfoxide (DMSO) was used to dissolve each nanoparticle and then added to $30 \mathrm{~mL}$ PDA, then autoclaved at $121^{\circ} \mathrm{C}$ for $30 \mathrm{~min}$. A pure culture of $P$. palmivora DD01 was cut by sterilized cock borer $(0.5 \mathrm{~mm})$ at the periphery of the colony, then these agar plugs were transferred to the middle of PDA mixed with each nanoparticle. The tested plates were maintained at room temperature $\left(27-30^{\circ} \mathrm{C}\right)$ and incubated until the tested pathogen completely covered control plates. The normal and abnormal structures of the tested pathogen were observed under a compound binocular microscope. The collected data were statistically analyzed using analysis of variance for colony size and sporangia number, then treatment means were compared using DMRT. The inhibition was computed as in previous experiments, and the effective dose (ED50) was calculated using probit analysis (SPSS Statistics v. 23.0, IBM Co., Armonk, NY, USA).

\section{Testing nano-CCE for phytoalexin production in Durian}

Seedlings of durian var. Monthong were inoculated with a sporangial suspension $\left(1 \times 10^{5}\right.$ sporangia/mL) of $P$. palmivora DD01 following cutting root tips before planting in a sterilized soil mixture of loamy soil:organic compost at the ratio of 9:1. The nano CC-E at a concentration of 15 mg. $\mathrm{kg}^{-1}$ was sprayed on the inoculated durian seedlings. Control plants were treated with sterile water (negative control) or scopoletin (positive control). Detection of phytoalexin in durian tissue extracts was carried out by thin layer chromatography (TLC) using $12 \%$ acetic acid. Fresh leaf samples ( 1 g.) were cleaned in tap water, ground, and soaked in $10 \mathrm{~mL}$ methanol before passing through a filter paper (Whatman No.4). The chromatogram was monitored under UV light (366 nm), and a single, blue fluorescent compound was characterized by comparison to the standard scopoletin (Sigma Co., Ltd.) at $R_{f} 0.75$. The $R_{f}$ value was calculated to compare with the scopoletin standard. The experiment was repeated three times. The $R_{f}$ value was calculated as (Equation 1):

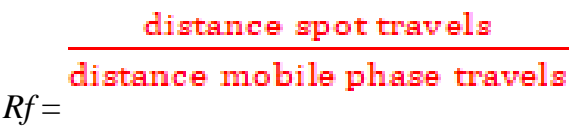

Where, $R f$ - retention factor. 


\section{Results}

\section{Isolation of pathogen}

The root rot pathogen of durian var. Monthong was isolated by a baiting technique. A pure culture of the fungal isolate was morphologically identified by observation under a compound microscope. Pure cultures grew very fast on potato dextrose agar and the colony covered the plate in 3 days. Agar discs $(1 \times 1 \mathrm{~cm})$ of the culture were cut and placed into sterile water and observed within $24 \mathrm{~h}$. Spherical sporangia, sporangiophore proliferation, zoospores released from pores of papulae were observed. Oogonia are round, and possessed amphigynous antheridia (Fig. 1).

\section{Molecular phylogeny of $P$. palmivola}

The phylogenetic tree showed a cluster of $P$. palmivola DD01 which is deposited in Genbank No. OL616293 expressing in the same clade with sequences of $P$. palmivola MG956799, HQ659668, MH219826, MH219849, KP813963, MH219829, MH219866, MH401200 from the Genbank database supported by an $88 \%$ bootstrap value with Sordaria tometoalba MH872281 as an outgroup (Fig. 2). All isolates were deposited at the Biocontrol Research Unit, Faculty of Agricultural Technology, King Mongkut's Institute of Technology Ladkrabang (KMITL), Bangkok, Thailand.

\section{Pathogenicity test}

The inoculated leaves of durian var. Monthong with $P$. palmivora DD01showed brown rot symptoms within 7 days. The leaves were significantly infected by the tested pathogen when compared to non-inoculated control which showed no symptoms (Fig. 3).

\section{Chaetomium antagonistic fungus}

C. cupreum CC 3003 was cultured on PDA for 3 weeks and colonies displayed yellow to orange or red to rust exudates. Ascomata superficial, ostiolate, subglobose or ovate with brown walls of textura angularis in the surface view. Terminal hairs usually arcuate, with apeces incurved, circinate to coiled. Lateral hairs flexuous or apically incurved. Asci fasciculate, clavate, with 8 biseriate or irregularly arranged ascospores, evanescent. Ascospores brown when mature, more or less inequilateral, fusiform, elongate fusiform, navicular, reniform, lunate or limoniform, sometimes bilaterally flattened, with one or two apical germ pores, while asexual stage is still unknown (Fig. 4).

\section{Molecular phylogeny of C. cupreum $\mathrm{CC3003}$}

Molecular phylogeny confirmed identification at the species

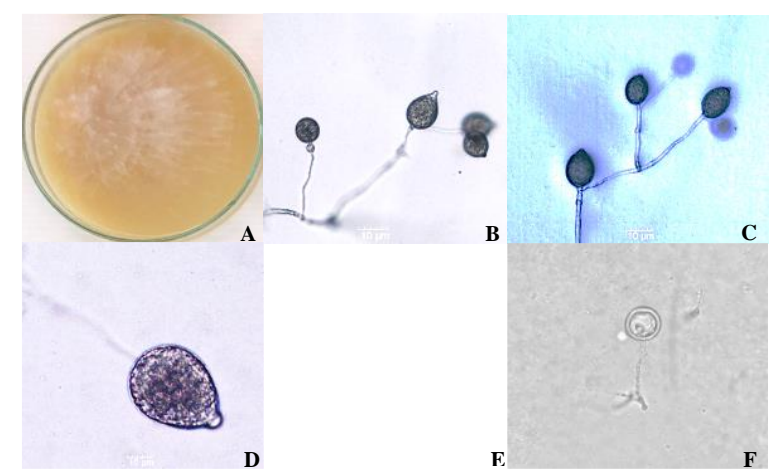

Fig. 1: Phytophthora palmivola, $\mathbf{A}=$ pure culture, $\mathbf{B} \& \mathbf{C}=$ sporangia and sporangial proliferation, $\mathbf{D}=$ sporangium, $\mathbf{E}=$ oogonium and anthridium, $\mathbf{F}=$ Oospore

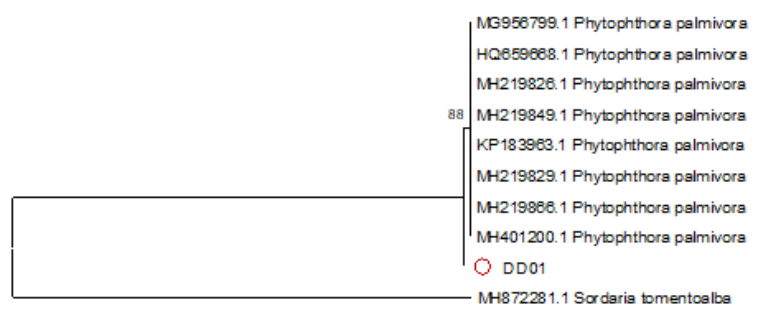

$\longmapsto$

Fig. 2: Phylogenic tree of Phythophthora palmivora from GenBank including Phythophthora palmivora strain DD01 constructed after distance based analyses of ITS1 and ITS4 regions of rDNA. Numbers of the branches indicate percentage of bootstrap values after1000 replicates. The outgroup taxa is Sordaria tomentoalba.

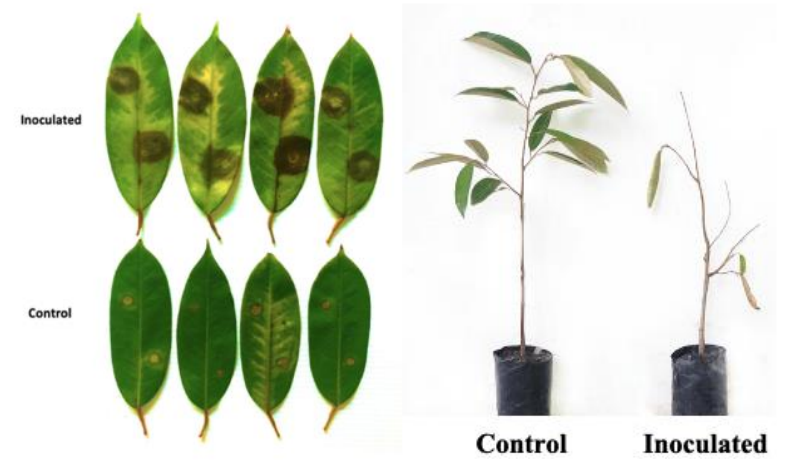

Fig. 3: Pathogenicity test of Phythophthora palmivora causing rot of durian var. Monthong on leaves and seedings.

level. The phylogenetic tree clearly identified Chaetomium spp. based upon the GeneBank database. Data from the GeneBank reliably confirmed CC3003 as C. cupreum (Fig. $5)$.

\section{Bi-culture test}

The results showed that C. cupreum strain CC 3003 


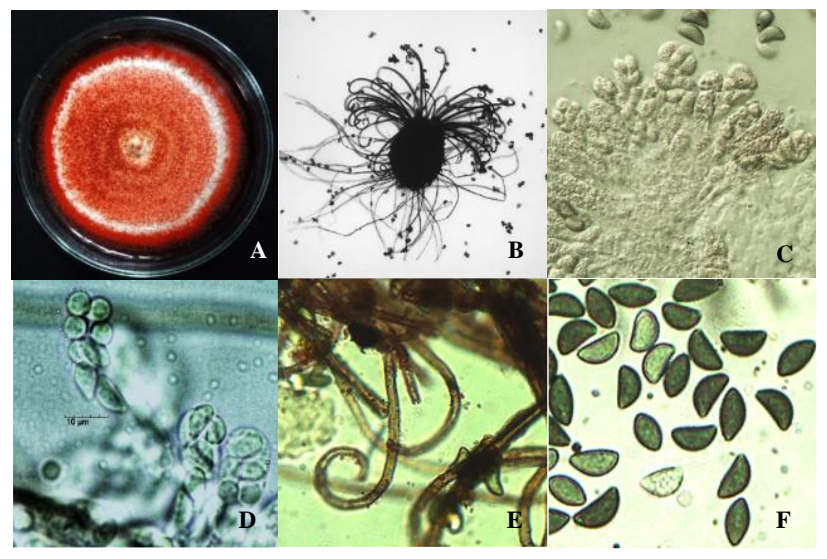

Fig. 4: C. cupreum strain Cc3003, $\mathbf{A}=$ pure culture, $\mathbf{B}=$ ascocarp, $\mathbf{C}-\mathbf{D}=$ asci, $\mathbf{E}=$ terminal ascomatal hairs, $\mathbf{F}=$ ascospores

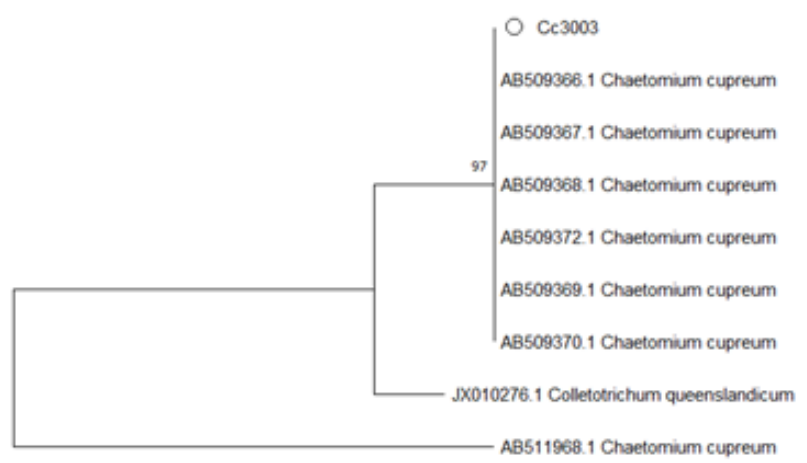

005

Fig. 5: Phylogenetic tree of Chaetomium cupreum from GenBank, including Chaetomium cupreum CC 3003, constructed based upon the distance-based analysis of the ITS1 and 5.8S regions of rDNA. The numbers at the branches indicate the percentage of bootstrap values after 1000 replications. The outgroup taxon is Colletotrichum queenslandicum.

significantly inhibited $P$. palmivora DD01 causing root rot of durian by over $80 \%$ in 3 weeks as seen in Fig. 6. The colony of Chaetomium grew over the pathogen colony in 4 weeks after incubation.

\section{Testing crude metabolites from $C$. cupreum $\mathrm{CC3003}$}

The results showed that all tested crude metabolites significantly inhibited colony growth and sporangial production of Phytophthora spp. at a concentration of 1,000 mg. $\mathrm{kg}^{-1}$ when compared to the controls. Crude CC-H, CC-E and $\mathrm{CC}-\mathrm{M}$ at $1,000 \mathrm{mg} \cdot \mathrm{kg}^{-1}$ did not significantly inhibit colony growth by 90,90 and $90 \%$ and spore production by 98, 72 and $98 \%$, respectively. The effective dose $\left(E_{50}\right)$ of CC-E, CC-H and CC-M for spore inhibition was 411, 158 and $482 \mathrm{mg} \cdot \mathrm{kg}^{-1}$, respectively (Table 1). Crude metabolites of $\mathrm{CC}-\mathrm{H}, \mathrm{CC}-\mathrm{E}, \mathrm{CC}-\mathrm{M}$ expressed antifungal activity to

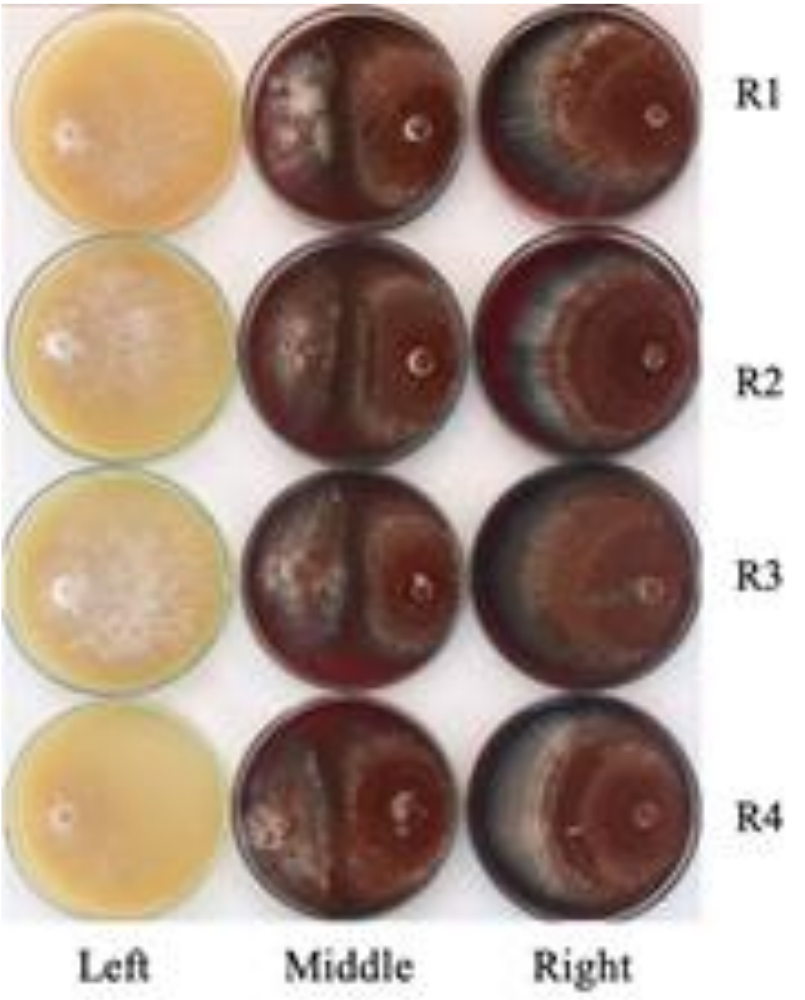

Fig. 6: C. cupreum strain CC 3003 vs. P. palmivora DD01 (Left represents $P$. palmivora; middle represents $C$. cupreum strain CC 3003 vs $P$. palmivora and right is $C$. cupreum strain CC 3003)

inhibit the growth of $P$. palmivora (durian rot disease) with $\mathrm{ED}_{50}$ values of 97,60 and $140 \mathrm{mg} \cdot \mathrm{kg}^{-1}$, respectively. Moreover, the spore production of $P$. palmivora was inhibited by crude metabolites of CC-H, CC-E, CC-M with the $\mathrm{ED}_{50}$ values of 97,60 and $140 \mathrm{mg} \cdot \mathrm{kg}^{-1}$, respectively (Table 1).

\section{Characterization of the nanoparticles}

The nanoparticles nano $\mathrm{CC}-\mathrm{H}$, nano $\mathrm{CC}-\mathrm{E}$ and nano $\mathrm{CC}-\mathrm{M}$, loaded with crude extracts from $C$. cupreum $\mathrm{CC} 3003$ were cream, light orange and light yellow in color, respectively (Fig. 7). Scanning electron images indicated that the particle size of nano CC-H, nano CC-E and nano CC-M averaged 534.1, 499.7 and 537.5 nm (Fig. 7).

\section{Evaluation of nanoparticles derived from $C$. cupreum against $\boldsymbol{P}$.palmivora}

Nanoparticles of C. cupreum CC3003 separately constructed using the electron spinning technique yielded nano $\mathrm{CC}-\mathrm{H}$ (crude hexane), nano $\mathrm{CC}-\mathrm{E}$ (crude ethyl acetate) and nano CC-M (crude methanol) as seen in Fig. 8. All tested nanoparticles derived from $C$. cupreum CC3003 at concentrations of $3,5,10$, and $15 \mathrm{mg} \cdot \mathrm{kg}^{-1}$ significantly 
Tongon et al. / Intl J Agric Biol, Vol 27, No 1, 2022

Table 1: Crude metabolites of Chaetomium cupreum CC3003 against Phytophthora palmivora

\begin{tabular}{|c|c|c|c|c|c|c|c|}
\hline $\begin{array}{l}\text { Crude } \\
\text { metabolites }\end{array}$ & $\begin{array}{l}\text { Concentration } \\
\left(\mathrm{mg} \cdot \mathrm{kg}^{-1}\right)\end{array}$ & $\begin{array}{l}\text { Colony } \\
(\mathrm{cm})^{12,3}\end{array}$ & $\begin{array}{l}\text { diameter Growth } \\
(\%)^{12,3}\end{array}$ & $\begin{array}{c}\text { inhibition } \mathrm{ED}_{50}\left(\mathrm{mg} \cdot \mathrm{kg}^{-}\right. \\
\left.{ }^{1}\right)\end{array}$ & $\begin{array}{l}\text { Number of } \\
12,3\left(10^{5}\right)\end{array}$ & $\begin{array}{r}\text { spores Spore } \\
(\%)^{1 / 2,3}\end{array}$ & $\begin{array}{c}\text { Inhibition } \mathrm{ED}_{50}\left(\mathrm{mg} \cdot \mathrm{kg}^{-}\right. \\
1)\end{array}$ \\
\hline & 0 & $5.00^{\mathrm{a}}$ & - & & $31.00^{c}$ & - & \\
\hline & 10 & $5.00^{\mathrm{a}}$ & $0^{f}$ & & $27.0^{\mathrm{ab}}$ & $13.03^{\mathrm{e}}$ & \\
\hline \multirow{3}{*}{ CC-H } & 100 & $5.00^{\mathrm{a}}$ & $0^{\mathrm{f}}$ & & $20.75^{\mathrm{c}}$ & $33.03^{\mathrm{cd}}$ & \\
\hline & 500 & $0.50^{f}$ & $90.00^{\mathrm{a}}$ & & $2.25^{\mathrm{e}}$ & $92.48^{\mathrm{a}}$ & \\
\hline & 1000 & $0.50^{\mathrm{f}}$ & $90.00^{\mathrm{a}}$ & & $0.50^{\mathrm{e}}$ & $98.33^{\mathrm{a}}$ & \\
\hline \multirow{7}{*}{ CC-E } & 10 & $2.32^{\mathrm{c}}$ & $53.50^{\mathrm{d}}$ & & $10.75^{\mathrm{d}}$ & $65.26^{\mathrm{b}}$ & \\
\hline & 50 & $1.97^{\mathrm{d}}$ & $60.50^{c}$ & 158.43 & $10.00^{\mathrm{d}}$ & $67.59^{\mathrm{b}}$ & 60.07 \\
\hline & 100 & $1.52^{\mathrm{e}}$ & $69.50^{\mathrm{b}}$ & & $8.25^{\mathrm{d}}$ & $72.90^{\mathrm{b}}$ & \\
\hline & 500 & $0.50^{f}$ & $90.00^{\mathrm{a}}$ & & $1.25^{\mathrm{e}}$ & $95.81^{\mathrm{a}}$ & \\
\hline & 1000 & $0.50^{\mathrm{f}}$ & $90.00^{\mathrm{a}}$ & & $0.25^{\mathrm{e}}$ & $99.13^{\mathrm{a}}$ & \\
\hline & 0 & $5.00^{\mathrm{a}}$ & - & & $31.00^{c}$ & - & \\
\hline & 10 & $5.00^{\mathrm{a}}$ & $0^{\mathrm{f}}$ & & $28.75^{\mathrm{a}}$ & $7.10^{\mathrm{ef}}$ & \\
\hline \multirow[t]{3}{*}{ CC-M } & 50 & $5.00^{\mathrm{a}}$ & $0^{\mathrm{f}}$ & & $28.75^{\mathrm{ab}}$ & $24.72^{\mathrm{d}}$ & 140.80 \\
\hline & 500 & $2.57^{\mathrm{b}}$ & $48.50^{\mathrm{e}}$ & & $9.50^{\mathrm{d}}$ & $68.52^{\mathrm{b}}$ & \\
\hline & 1000 & $0.50^{\mathrm{f}}$ & $90.00^{\mathrm{a}}$ & & $0.50^{\mathrm{e}}$ & $98.33^{\mathrm{a}}$ & \\
\hline C.V. (\%) & & 4.25 & 7.06 & & 15.49 & 14.20 & \\
\hline
\end{tabular}

Table 2: Activity of nanoparticles of Chaetomium cupreum CC3003 against Phytophthora palmivora

\begin{tabular}{|c|c|c|c|c|c|c|c|c|}
\hline Metabolites & $\begin{array}{l}\text { Concentration } \\
\left(\mathrm{mg} \cdot \mathrm{kg}^{-1}\right)\end{array}$ & $\begin{array}{l}\text { Colony } \\
(\mathrm{cm})^{/ 2,3}\end{array}$ & $\begin{array}{c}\text { diameter Growth } \\
(\%)^{12,3} \\
\end{array}$ & $\begin{array}{c}\text { inhibition } \mathrm{ED}_{50}\left(\mathrm{mg} \cdot \mathrm{kg}^{-}\right. \\
\left.{ }^{1}\right)\end{array}$ & $\begin{array}{l}\text { Number } \\
/ 2,3\left(10^{5}\right)\end{array}$ & of & $\begin{array}{r}\text { spores Spore } \\
(\%)^{12,3} \\
\end{array}$ & $\begin{array}{c}\text { Inhibition } \mathrm{ED}_{50}(\mathrm{mg} \cdot \mathrm{kg} \\
\left.{ }^{1}\right)\end{array}$ \\
\hline Nano CC-H & 0 & $5.00^{\mathrm{a} 1}$ & - & \multirow{5}{*}{1.78} & $29.25^{\mathrm{a}}$ & & - & \multirow{5}{*}{13.03} \\
\hline & 3 & $2.31^{\mathrm{b}}$ & $53.75^{\mathrm{c}}$ & & $4.00^{\mathrm{b}}$ & & $86.16^{\mathrm{d}}$ & \\
\hline & 10 & $0.56^{\mathrm{d}}$ & $88.75^{\mathrm{a}}$ & & $0.50^{\mathrm{cd}}$ & & $97.49^{\mathrm{ab}}$ & \\
\hline & 15 & $0.50^{\mathrm{d}}$ & $90.00^{\mathrm{a}}$ & & $0.50^{\mathrm{cd}}$ & & $98.38^{\mathrm{a}}$ & \\
\hline & 0 & $5.00^{\mathrm{a}}$ & - & & $29.25^{\mathrm{a}}$ & & - & \\
\hline \multirow{5}{*}{ Nano CC-E } & 5 & $1.22^{\mathrm{c}}$ & $75.50^{\mathrm{b}}$ & \multirow[t]{5}{*}{1.51} & $1.50^{\mathrm{cd}}$ & & $94.81^{\mathrm{bc}}$ & \multirow[t]{5}{*}{11.01} \\
\hline & 10 & $0.50^{\mathrm{d}}$ & $90.00^{\mathrm{a}}$ & & $0.50^{\mathrm{cd}}$ & & $98.36^{\mathrm{a}}$ & \\
\hline & 15 & $0.50^{\mathrm{d}}$ & $90.00^{\mathrm{a}}$ & & $0.25^{\mathrm{d}}$ & & $99.16^{\mathrm{a}}$ & \\
\hline & 0 & $5.00^{\mathrm{a}}$ & - & & $29.25^{\mathrm{a}}$ & & - & \\
\hline & 3 & $2.31^{\mathrm{b}}$ & $53.75^{\mathrm{c}}$ & & $4.50^{\mathrm{b}}$ & & $84.70^{\mathrm{d}}$ & \\
\hline Nano CC- & 5 & $0.56^{\mathrm{d}}$ & $88.75^{\mathrm{a}}$ & \multirow[t]{3}{*}{1.19} & $1.50^{\mathrm{cd}}$ & & $94.83^{\mathrm{bc}}$ & \multirow[t]{3}{*}{16.48} \\
\hline \multirow[t]{2}{*}{ M } & 10 & $0.50^{\mathrm{d}}$ & $90.00^{\mathrm{a}}$ & & $0.75^{\mathrm{cd}}$ & & $98.21^{\mathrm{ab}}$ & \\
\hline & 15 & $0.50^{\mathrm{d}}$ & $90.00^{\mathrm{a}}$ & & $0.50^{\mathrm{cd}}$ & & $98.33^{\mathrm{a}}$ & \\
\hline
\end{tabular}

inhibited colony growth and spore production when compared to the non-treated control $\left(0 \mathrm{mg} \cdot \mathrm{kg}^{-1}\right)$. The highest tested concentration of $15 \mathrm{mg} \cdot \mathrm{kg}^{-1}$ gave the highest inhibition of colony growth and spore production. The nano-CC-E, nano-CC-H and nano-CC-M were actively antifungal against $P$. palmivora with the $\mathrm{ED}_{50}$ of 11,13 and 16 mg. $\mathrm{kg}^{-1}$, respectively (Table 2). Moreover, nano-CC-E, nano-CC-H and nano-CC-M measured under SEM showed sizes of 534, 499 and $537 \mathrm{~nm}$ respectively.

\section{Phytoalexin production}

The current research found that nano-CCE derived from $C$. cupreum CC3003 at a concentration of $15 \mathrm{mg} \cdot \mathrm{kg}^{-1}$ used to treat seedlings of durian var. Monthong inoculated with $P$. palmivora expressed a spot on TLC with an $R_{f}$ value of 0.75 which proved to be scopoletin (Fig. 9).

\section{Discussion}

The fungal pathogen caused root rot disease in durian var. Monthong was identified morphologically and molecularly as $P$. palmivora DD01. Widmer (2014) stated that $P$. palmivora is a cosmopolitan pathogen causing rot of cacao, papaya, black pepper, rubber, coconut, and citrus. $P$. palmivora is heterothallic with amphigynous antheridia and spherical oogonia. Sporangia are papillate, varying in shape from ovoid-ellipsoid. Chlamydospores are terminal and intercalary. $P$. palmivora DD01 found to be a virulent isolate causing brown rot symptoms within 7 days. The 


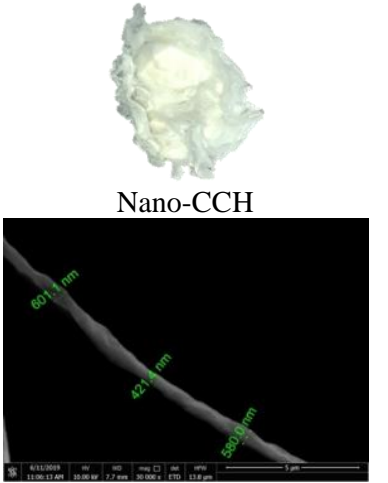

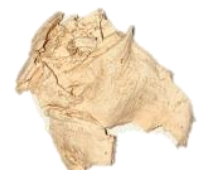

Nano-CCE

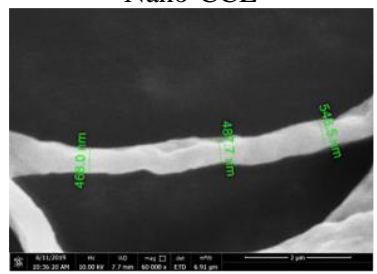

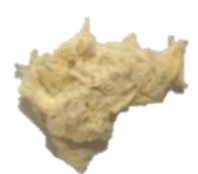

Nano-CCM

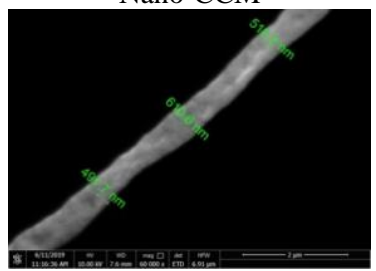

Fig. 7: Nanoparticles of Chaetomium cupreum CC3003
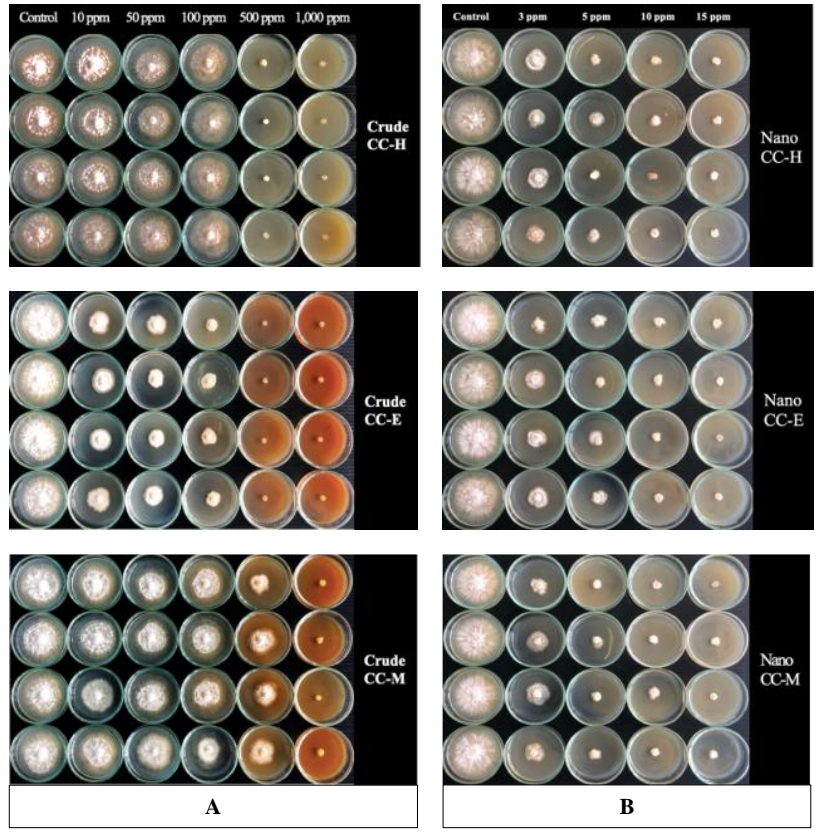

Fig. 8: Inhibition of Phytophthora palmivora DD1 using crude extracts (A) and nanoparticles (B) derived from Chaetomium cupreum CC3003. Note: Crude CC-H, Crude CC-E, and Crude $\mathrm{CC}-\mathrm{H}$ represented crude extracts from hexane, ethyl acetate and methanol, and nano $\mathrm{CC}-\mathrm{H}$, nano $\mathrm{CC}-\mathrm{E}$ and nano $\mathrm{CC}-\mathrm{M}$ represented nanoparticles constructed from hexane, ethyl acetate and methanol crude extracts

leaves were significantly infected by the tested pathogen. This was similarly reported by Tongon et al. (2018). The inoculated seedling roots with $P$. palmivora showed root rot and die back within 15 days when compared to the noninoculated seedlings of durian var. Monthong which exhibited no symptoms. Those results were in accordance with Pechprome and Soytong (1996) who stated that durian var. Monthong stem and root rot was caused by $P$. palmivora. Morphology and molecular techniques confirmed the identity of $C$. cupreum CC3003. Bi culture tests showed that $C$. cupreum CC3003 inhibited the growth

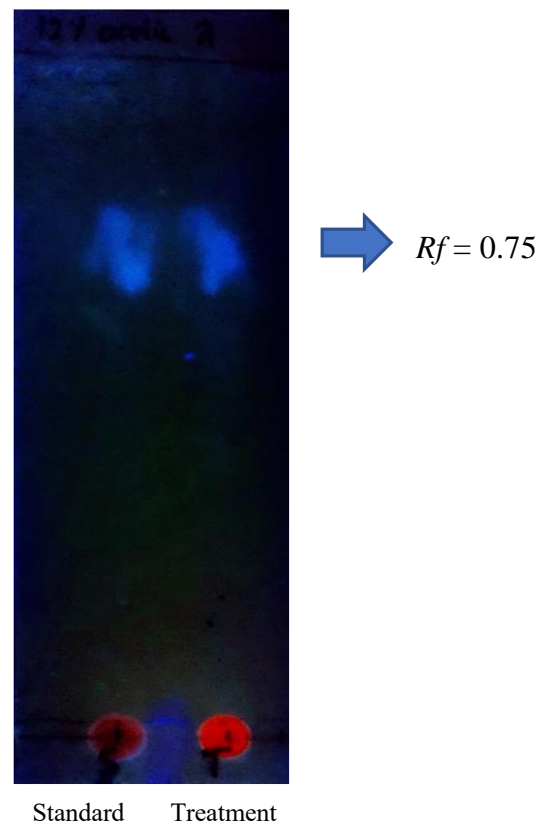

Fig. 9: Phytoalexin investigation

of $P$. palmivora. The research finding was similar to a report of Soytong and Quimio (1992) which found that $C$. cupreum actively inhibited Pyricularia oryzae causing rice blast. Scanning electron images indicated that the particle size of nano $\mathrm{CC}-\mathrm{H}$, nano $\mathrm{CC}-\mathrm{E}$ and nano $\mathrm{CC}-\mathrm{M}$ averaged 534.1, 499.7 and $537.5 \mathrm{~nm}$. Song et al. (2020) reported that nano-CCoH, nano-CCoE and nano-CCoM from $C$. cochliodes (CTh05) ranged between 567-611, 422-566 and 415-472 nm, respectively. The fungal metabolites of $C$. cupreum CC3003 (CC-H, CC-E, CC-M) expressed antifungal activity against $P$. palmivora isolate DD01 highly inhibited colony growth by $90 \%$ and spore production by 98, 72 and $98 \%$, respectively. The current research was similar to that of Song and Soytong (2018) who found that crude extracts from Chaetomium spp. gave the significantly highest sporulation inhibition of Magnporthe spp. of $88 \%$, at $1,000 \mathrm{mg} \cdot \mathrm{kg}^{-1}$. Nanoparticles of C. cupreum CC3003 
separately constructed using the electron spinning technique as report by Song et al. (2020). Phytoalexin production was done by using Thin layer chromatography (TLC) and observed under UV light found blue fluorescent spot that similar as Power and Moore (1909) stated that the $R_{f}$ value of paper chromatography for scopoletin was 0.75 which $6 \%$ AcOH and $\mathrm{H}_{2} \mathrm{O}$-saturated isoamyl alcohol at the ratio of 1:1 expressed an $R_{f}$ value of 0.75 , and $\mathrm{BuOH}: \mathrm{AcOH}: \mathrm{H}_{2} \mathrm{O}_{4}$ at the ration of 1:2:2 showed an $R_{f}$ value of 0.75 . Scopoletin was detected by fluorescence under an ultraviolet lamp. Einhellig et al. (1970) stated that when scopoletin was used to treat tobacco, sunflower and pigweed seedlings, scopoletin increased significantly in the tissue when compared with the control. Our research finding is consistent with Costet et al. (2002) who found that scopoletin accounted for the fluorescence after extraction by thin layer chromatography. As a result, nano-CCE constructed from $C$. cupreum CC3003 induced the test plant to produce scopoletin with activity against $P$. palmivora causing root rot of durian. Similarly, Sun et al. (2014) reported that scopoletin found in tobacco plants exhibited strong antifungal activity against $A$. alternata causing disease in tobacco.

\section{Conclusion}

CC-H, CC-E, CC-M are crude metabolites of C. cupreum CC3003 that inhibited the colony growth of $P$. palmivora with $\mathrm{ED}_{50}$ values of 97,60 and $140 \mathrm{mg} \cdot \mathrm{kg}^{-1}$, respectively and inhibited the inocula production of the pathogen with the $\mathrm{ED}_{50}$ values of 97,60 and $140 \mathrm{mg} \cdot \mathrm{kg}^{-1}$, respectively. The constructed nano-CC-E, nano CC-H and nano CC-M from C. cupreum CC3003 significantly inhibited the inocula production of $P$. palmivora with the ED ${ }_{50}$ of 11,13 and 16 $\mathrm{mg} . \mathrm{kg}^{-1}$. The nano CC-E constructed from C. cupreum CC3003 at a concentration of $15 \mathrm{mg} \cdot \mathrm{kg}^{-1}$ used to treated seedlings of durian var. Monthong inoculated with $P$. palmivora clearly showed the production of scopoletin $\left(R_{f}\right.$ value 0.75 ) as a phytoalexin produced by the seedlings. It was concluded that the active strain of C. cupreum CC3003 produced crude metabolites and the constructs of nanoparticles which inhibited inoculum production by $P$. palmivora. All tested nanoparticles derived from $C$. cupreum CC3003 more effectively inhibited the tested pathogen than the crude metabolites. It was noticed that the treatment of inoculated durian plants with nano-CCE induced scopoletin production.

\section{Acknowledgements}

I would like to thank the Association of Agricultural Technology in Southeast Asia (AATSEA) for providing some part of research facilities as it is a partly of Ph.D. dissertation at King Mongkut's Institute of Technology Ladkrabang, Bangkok, Thailand.

\section{Author Contributions}

Tongon, R.: Performed in the experiment, writing original draft and anlyzed data. Soytong, K.: Conceptualization, resources, proofreading and editing.

\section{Conflict of Interest}

The authors declare no conflict of interest.

\section{Data Availability}

The reported data can be made available upon requesting to the corresponding author

\section{Ethics Approval}

Not applicable in this research work.

\section{References}

Ahuja I, R Kissen, AM Bones (2012). Phytoalexins in defense against pathogens. Trends Plant Sci 17:73-90

Angelova Z, S Georgiev, W Roos (2006). Elicitation of plants. Biotechnol Equip 20:72-83

Arx JAV, J Guarro, MJ Figueras (1986). The Ascomycete Genus Chaetomium. Beihefte zur Nova Hedwigia vol. 84. Lubrecht \& Cramer, Berlin, Germany

Costet L, B Fritig, S Kauffmann (2002). Scopoletin expression in elicitortreated and tobacco mosaic virus-infected tobacco plants. Physiol Plant 115:228-235

Dar J, K Soytong (2014). Construction and characterization of copolymer nano materials loaded with bio active compounds from Chaetomium species. Intl J Agric Technol 10:823-831

Deverall BJ (1982). Introduction. In: Phytoalexins, pp:1-20. Bailey JA, JW Mansfield (Eds). Blackie, London

Ditta A (2012). How helpful is nanotechnology in agriculture? Adv Nat Sci Nanosci Nanotechnol 3:1-10

Einhellig FA, EL Rice, PG Risser, SH Wender (1970). Effects of scopoletin on growth, $\mathrm{CO} 2$ exchange rates, and concentration of scopoletin, scopolin and chlorogenic acids in tobacco, sunflower and pigweed. Bull Torr Bot Club 97:22-33

Elibol OH, D Morisette, D Akin, JP Denton, R Bashir (2003). Integrated nanoscale silicon sensors using top-down fabrication. Appl Phys Lett 83:4613-4615

Erwin DC, OK Ribeiro (1996). Phytophthora Diseases Worldwide. St. Paul: APS Press, Minnesota, USA

Ferrer C, F Colom, S Frasés, E Mulet, JL Abad, JL Alió (2001). Detection and identification of fungal pathogens by PCR and by ITS2 and $5.8 \mathrm{~S}$ ribosomal DNA typing in ocular infections. J Clin Microbiol 39:2873-2879

Glazebrook J, FM Ausubel (1994). Isolation of phytoalexin-deficient mutants of Arabidopsis thaliana and characterization of their interactions with bacterial pathogens. Proc Natl Acad Sci 91:8955-8959

Gnonlonfin GJB, A Sammi, L Brimer (2012). Review Scopoletin-A coumarin phytoalexin with medicinal properties. Crit Rev Plant Sci 31:47-56

Graham GC, P Mayers, RJ Henry (1994). A simplified method for the preparation of fungal genomic DNA for PCR and RAPD analysis. Biotechniques 16:48-50

Husin NA, S Rahman, R Karunakaran, SJ Bhore (2018). A review on the nutritional, medicinal, molecular and genome attributes of Durian (Durio zibethinus L.), the King of fruits in Malaysia. Bioinformation 14:265-270 DOI:10.6026/97320630014265 
Jiang C, J Song, J Zhang, Q Yang (2017). Identification and characterization of the major antifungal substance against Fusarium Sporotrichioides from Chaetomium globosum. World J Microbiol Biotechnol 33:108

Kanokmedhakul S, K Kanokmedhakul, P Nasomjai, S Louangsysouphanh, K Soytong, M Isobe, A Suksamrarn (2006). Antifungal azaphilones from the Fungus Chaetomium cupreum CC3003. J Nat Prod 69:891-895

Li M, Q Huang, Y Wu (2011). A novel chitosan-poly(lactide) copolymer and its submicron particles as imidacloprid carriers. Pest Manage Sci 67:831-836

Liu L, ZK Punja, JE Rahe (1995). Effect of Pythium spp. and glyphosate on phytoalexin production and exudation by bean (Phaseolus vulgaris L.) roots grown in different media. Physiol Mol Plant Pathol 47:391-405

Palmieri D, E Portillo, Y Sulbarán, M Guerra, E San-Blas (2019). Biocontrol of Phytophthora root and stem rot disease in papaya (Carica papaya) plants by Photorhabdus, the symbiont bacterium of Heterorhabditis amazonensis. BioControl 64:595-604

Pechprome S, K Soytong (1996). Integrated biological control of durian stem and root rot caused by Phytophthora palmivora. In: Proceedings of the first International Symposium on Biopesticides, pp:228-237. Thailand

Perlatti B, PLD Souza Bergo, JB Fernandes, MR Forim (2013). Polymeric nanoparticle-based insecticides: a controlled release purpose for agrochemicals. In: Insecticides-Development of safer and more effective technologies. IntechOpen doi:10.5772/53355

Power FB, CW Moore (1909). XXXII.-The constituents of the bark of prunus serotina. Isolation of 1-mandelonitrile glucoside. J Chem Soc Trans 95:243-261

Rai M, A Ingle (2012). Role of nanotechnology in agriculture with special reference to management of insect pests. Appl Microbiol Biotechnol 94:287-293

Shanthiyaa V, D Saravanakumar, L Rajendran, G Karthikeyan, K Prabakar, T Raguchander (2013). Use of Chaetomium globosum for biocontrol of potato late blight disease. J Crop Prot 52:33-38

Song J, K Soytong (2018). Nano-particles from Chaetomium against Rice Blast. bioRxiv 2018:1-14 doi: https://doi.org/10.1101/339283
Song J, K Soytong, S Kanokmedhakul, K Kanokmedhkul, S Poeaim (2020). Natural product of nano-particles constructed from Chaetomium spp. to control rice blast disease caused by Magnaporthe oryzae. Intl J Agric Biol 23:1013-1020

Soutter W (2012). Nanotechnology in agriculture - Azono: The A-Z of nanotechnology. Available at: http://www.azonano.com/ar ticle.aspx? ArticleID=3141 (Accessed: 30 April 2012)

Soytong K (2010). Evaluation of chaetomium-biological fungicide to control phytophthora stem and root rot of durian. Res J 3:117-124

Soytong K (1989). Antagonism of Chaetomium cupreum to Pyricularia oryzae: A case study to biocontrol of a rice blast disease. Thai Phytopathol 9:28-33

Soytong K, TH Quimio (1992). Antagonism of Chaetomium cupreum to Pyricularia oryzae. J Plant Prot Trop 9:17-23

Soytong K, TH Quimio (1989). A taxonomic study on the Philippine species of Chaetomium. Phil Agric Sci 72:59-72

Subhadrabandhu S, M Shodal (1997). Effect of time and degree of flower thinning on fruit set, fruit growth, fruit characters and yield of durian. J Nat Sci 31:218-222

Sun H, L Wang, B Zhang, J Ma, C Hettenhausen, G Cao, J Wu (2014). Scopoletin is a phytoalexin against Alternaria alternata in wild tobacco dependent on Jasmonate signalling. $J$ Exp Bot 65:4305-4315

Tann H, K Soytong (2016). Bioformulations and nano product from Chaetomium cupreum CC3003 to control leaf spot of rice var. Sen Pidoa in Cambodia. Intl J Plant Biol 7:59-63

Thiep NV, K Soytong (2015). Chaetomium spp. as biocontrol potential to control tea and coffee pathogens in Vietnam. Intl J Agric Technol 11:1381-1392

Tongon R, K Soytong, S Kanokmedhakul, K Kanokmedhakul (2018). Nano-particles from Chaetomium brasiliense to control Phytophthora palmivora caused root rot disease in durian var. Montong. Intl J Agric Technol 14:2163-2170

Widmer TL (2014). Phytophthora palmivora. For Phytoph 4:1-5 DOI:10.5399/osu/fp.4.1.3557

Yean HC, M Atong, KP Chong (2009). Lettucenin A and its role against Xanthomonas campestris. J Agric Sci 1:66-70 